\title{
予習時の質問生成への介入および解答作成が授業理解に 与える影響とそのプロセスの検討
}

\author{
篠ヶ谷 圭 太*
}

\begin{abstract}
本研究では, 学習者の保持する意味理解志向に着目しながら, 予習時の質問生成への介入および質問 に対する解答作成の効果について検討を行った。中学 2 年生 87 名を対象とした 5 日間の歴史の実験授業 を実施し，予習時に自由に質問を生成する群 (自由質問群) と, 質問生成に介入を行う群 (質問介入群), 質 問生成に介入を行った上で解答を作成する群（質問介入+解答作成群）の 3 条件を設定した。本研究の結果， 質問の生成の仕方に介入を行うことで，意味理解志向の低い学習者の質問がより高次な内容を問う質問 へと変容し, 授業では質問に関連する情報のメモが増加することが示された。また, 生成した質問に対 して解答作成を行うことで, 授業での情報の比較や統合処理が促され, 授業理解が促進されることが示 唆された。
\end{abstract}

キーワード：予習, 質問生成, 質問への解答作成, 学習観, 歴史学習

\section{問題と目的}

テキストや講義の内容を深く理解し, 知識を習得す るためには，関連する内容について事前に学習してお くことが有効である。たとえば，講演やシンポジウム を聞きに行く際に，事前にパンフレットなどで発表の 概要を読んでおいたことで, 当日の内容をより深く理 解できたといった経験をした人は少なくないであろう。

このように, 事前に学習を行いながら, 自らの理解 を深めていくスキルは, 生涯学び続けていく上で不可 欠であり, 学校教育の段階で身に付けておく必要があ る。そのために学校教育において重視されるべき活動 が予習である。児童や生徒が営む日久の学習は, 学校 の授業だけで成立しているわけではなく，家庭での予 習や復習を含んで扔り，予習一授業一復習というサイ クル構造を成している (e.g., 市川, 2004)。予習はこのサ イクルの始発点にあたる活動として, 深い授業理解や 質の高い復習を実現する上で重要な役割を果たすと考 えられる。基礎学力の向上, そして, 生涯に渡って効 果的に学び続けていくスキルの育成のためには, 学校 教育において, より積極的に予習を指導していく必要 があるといえる。

本稿における予習の定義 予習は「次に学ぶところ を前もって学習しておくこと (広辞苑)」と定義される。 認知的構成主義の立場では, 学習とは「入力された情 報について, 既有知識に基づきながら, 認知的処理や

* 日本大学経済学部
メ夕認知的処理を用いて, 内的表象を作り上げること」 と捉えられている (e.g., Mayer, 1996)。そのため, 本研 究では, こうした立場に基づき, 予習を「授業内容に 関連する情報が提示され, 学習者が既有知識を用いな がら, 認知的, メ夕認知的処理を行うこと」と定義す る。一般に, 学校現場における予習は, 「授業の概略を 摑んでおくこと」や「疑問点をチェックしておくこと」 といったように, 非常に狭義なものとして捉えられて いると考元られるが, 本研究の定義からすると, その ような予習とは, 学習者が予習の中で行っている認知 的・メ夕認知的処理の一つであることに留意されたい。

事前知識の提示の効果と個人差 これから学習する 内容に関する知識を事前に提示することの効果は, 主 に先行オーガナイザー研究において検討されてきた。 そうした研究では, 事前に知識が与えられることで, その後の学習において, それらの知識間の関連や, よ り詳細な情報の理解が促進されることが示されてきた (e.g., Ausubel, 1960 ; Mayer, 1983)。

このような効果を理解する上で有用なのが, Mayer (1996) の「SOI モデル」である。SOI モデルでは, テ キストや解説講義をもとに概念を理解し, 知識を習得 していく場合, 学習者はまず重要な情報を選択し (selecting), 構造化した上で (organizing), 自らの既有 知識との比較や統合 (integrating) を行うとされてい る。新奇な情報を既有知識に組み込みやすくするため に先行オーガナイザーが提唱された経緯から考えれば, 事前に個々の知識を得ることで, その後の学習内容の 理解が促進されるのは, 事前知識によって SOI モデル 
における「比較・統合」処理が容易になるためである と考えられる。

しかし，事前に知識を提示したとしても，期待され る効果が得られるとは限らない。この点について, 篠ヶ 谷 (2008) は, 中学生の歴史学習を対象に教科書を読ん で予習しておくことの効果とその個人差について検討 している。ここで対象とされた歴史の授業とは, 教科 書に記述されている史実を扱いながら，その背景因果 を新たに解説していくものである。Mayer (1983) など の知見から考えれば，「どのような出来事が起こった か」といった知識を事前に得ておくことで，授業では 「なぜそのような出来事が起こったのか」といった背 景因果の理解が促進されると考えられる。ところが, 篠ヶ谷 (2008) では，そのような予習の効果は，学習者 の信念である意味理解志向（知識のつながりを重視する姿 勢)の高い学習者ほど大きく, 意味理解志向の低い学習 者ではそうした効果は得られないことが報告されてい る。

授業理解を促進する予習とはこのような結果を先 述の SOI モデルに基づいて解釈するならば, 情報の選 択プロセスが関連しているものと考えられる。つまり， たとえ事前に史実の知識を得ていても，授業中の背景 因果情報に注意が向けられなければ，因果理解は促進 されないと考えられる。実際のところ, 篠ヶ谷 (2008) では，授業中の背景因果情報のメモにおいて，意味理 解志向による個人差が生じており，同じ教科書情報が 事前に与えられても, 授業で選択される情報が異なる ために, 因果理解の深まりに個人差が生じてしまうこ とが示されている。

では，なぜ授業での情報選択に違いが生じてしまう のであろうか。ここで重要となるのが, 予習中の学習 者の認知的, メ夕認知的処理である。すなわち, 学習 者の信念によって, 予習中に行っている処理が異なる ために，授業での情報選択に個人差が生じている可能 性が考えられる。そのため，単に教科書を読んで予習 した場合に生じる個人差の原因について検討を行い, 多くの学習者を深い因果理解へと方向づけるための具 体的な予習活動を明らかにしていく必要があるといえ る。

予習時の質問生成への着目 この点について, 本研 究では, 予習中に学習者が生成している質問に着目す

質問とは, 対象（教科書や講義など）に対して感じた疑問を 明確化することで生成されると考えられている (e.g., Dillon, 1988 ; 生田・丸野, 2005)。そのため, 本研究では, 質問を「学 習中の疑問を明確化したもの」と定義することとする。
る。意味理解志向とは学習において知識のつながりの 理解を重視する姿勢であるため, 意味理解志向の高い 学習者ほど, 個々の史実の知識を得た際に, それらの 背景因果や史実間の関連に関する質問を生成している 可能性がある。

質問生成に関するこれまでの研究では，どのような 学習者がどのような質問を生成するのかについて多く の検討が行われてきた。しかし, 先行研究では, 学習 者の既有知識の量が質問生成に影響することは示され ているものの (e.g., Miyake \& Norman, 1979 ; Van der Meij, 1990), 学習者の保持する信念と質問生成の関連につい ては検討されていない。学習者の保持する信念は, 学 習に対する動機づけや方略使用, 学習時の目標設定な ど，様々な変数に影響を及ぼす重要な変数であること が指摘されていることから (e.g., Dahl, Bals, \& Turi, 2005 ; Kardash \& Howell, 2000), 学習者の意味理解志向の高さ によって，予習時に生成する質問の質が異なっており， それが授業理解の個人差へとつながっている可能性は 十分に考えられる。

もしそうなのであれば, 歴史学習において, 事前に 教科書を読んで予習を行わせる際にも, 史実の背景因 果を問うような質問を生成するように介入を行うこと で, 授業では背景因果情報の選択が促され, 因果理解 が促進されるものと予想される。先行研究においては 「What」や「How」など質問文の最初の語句を指定す ることで, その後の学習の理解が促進されることは報 告されているが (e.g., King, 1992), 生成する問いが変化 することで, その後の学習での情報処理に生じる影響 まで明らかにされているわけではない。そこで本研究 では, 1 つ目の目的として, 学習者の保持する信念と 予習時の質問生成の関係に着目しながら, 予習を行う 際の質問生成に対する介入の効果について検討を行う。

質問に対する解答作成への着目 ただし, 先行研究 では，質問生成に対する介入の効果が一貫していない ことも指摘されており (e.g., Rosenshine, Meister, \& Chapman, 1996), 単に質問の生成方法に介入を行っただけで は, 授業理解が促進されない可能性がある。Pressley, Tanenbaum, McDaniel, \& Wood (1990) では, 学習 前に提示された質問に対し，解答を作成することでそ の後の学習が促進されることが示されており, Hamilton（1985）は，問いに対して推論を行うことで, その後の学習の目標認識が促されることを指摘してい る。しかし, これまでの研究では, 事前に解答を作成 しておくことで学習者の情報処理のどのような側面が 促されるために理解が促進されるのかは明らかにされ 
ていない。そこで本研究では，2つ目の目的として， 生成した質問に対する解答作成の効果についても検討 を行うこととする。

本研究の枠組み 1 つ目の目的に関して, 本研究で は，教科書を読んで予習を行う際に，自由に質問を生 成させる群(自由質問群) と，質問の生成方法に介入を行 う群(質問介入群) 設定し, 学習者の意味理解志向の影 響に着目しながら，質問への介入の効果の検討を行う。 自由に質問を生成する群(自由質問群)では, 意味理解志 向の低い学習者は，教科書を読んだ際に史実の背景因 果や関係性に関する質問をあまり生成しないものと考 えられるが, 予習時の質問生成に対して介入する群(質 問介入群) では, 意味理解志向の低い学習者の生成する 質問の質が变容すると考えられる。また，背景因果や 知識の関係性を問う質問へと変容することで，授業で の情報選択に変化が生じ, 授業理解にも影響が生じる ものと予想される。

2 つ目の目的に関しては, 質問生成に対して介入を 行うだけでなく，生成した質問に対して予習の中で解 答作成も行う群（質問介入十解答作成群）を設定する。 Hamilton (1985)の指摘から考えると, 生成した質問に 対して解答を作成することで, 授業目標の認識が促さ れることが期待される。それに伴い, 授業中の情報選 択に影響が見られ, 授業理解が促進されるものと予想 される。

\section{方法}

参加者 夏休みに東京都の国立大学で開かれた学習 講座に参加した文京区, 台東区の公立中学校, および 国立大学附属中学校の 2 年生 87 名（男子 49 名, 女子 38 名)。郵送により参加を呼びかけ, 応募してきた生徒を 参加者とし, 自由質問群 29 名, 質問介入群 29 名, 質 問介入十解答作成群 29 名の 3 群に配置した。各群を編 成する際には公立中学校の生徒と国立大学附属中学校 の生徒の割合に偏りが生じないよう配慮した。

事前質問紙 学習講座開始の 1 ケ月前に質問紙を郵 送し, 歴史学習に対する意味理解志向や事前の学力に ついて測定を行った。意味理解志向とは, 知識同士の 関連の理解を重視する姿勢であり, 項目は篠ヶ谷(2008) を参考に,「歴史の勉強では, 習ったことのつながりを 考えることが大切だ」など 4 項目を使用した。回答は 1 (まったくあてはまらない) から 5 (とてもよくあてはまる) の 5 件法で評定してもらった。また, 参加者の事前の 学力については 1 学期の成績表のうち, 5 教科(英語, 国 語, 数学, 社会, 理科) の数值を 5 段階評定值で報告しても
らった。

学習講座の概要 学習講座全体の構成は篠ヶ谷 (2011) と同様であった。講座は計 5 日間実施され, 大 学の同一の教室で, 筆者本人によって行われた。科目 は歴史で，単元は第一次世界大戦を扱った。教材は日 本書籍の中学社会科 (歴史的分野) を主に使用した。

1 回の授業は 50 分であり, 約 10 分の予習時間と約 40 分の解説講義で構成された ${ }^{2}$ 。 1 回の授業では教科 書約 2 ページ分の内容を扱い, 教科書の記述にある 個々の史実について板書で簡単にまとめた上で, なぜ そのような出来事が起こったのか, なぜその国 (人物) がそのような行動をとつたのかについて解説を行った。 たとえば,「イギリスはインド, エジプト, 南アフリカ を支配し，3 C 政策を展開した」という教科書の記述 に対し, 解説講義では, イギリスがそれぞれの地を支 配した理由について, 必要に応じて黒板に地図を描き ながら解説を行った。授業は 1 日おきに計 4 回実施さ れ，5 日目に 4 回の授業内容に関する理解度を測定す るテストを実施した。5 日目にテストがあることは初 回の授業時に参加者全員に伝えられた。また, 群間で 講義の内容に差が生じないように事前に入念にリハー サルを行い，授業の実施順にはカウンターバランスを 施した。

質問生成への介入 毎回の予習時間では, その日に 扱う部分の教科書のコピーと「質問書き出しシート」 が配付され，参加者は教科書を読んだ上で，よく分か らなかったところや疑問に思ったところを質問として 書き出すよう指示された。なお，授業で扱われない内 容に関する質問を生成してしまうといった問題 (c.f., 篠ヶ谷, 2011）が極力生じないよう, 教科書のコピーに は, 授業で重点的に扱う部分にあらかじめ下線が引か れており，参加者は下線部に関して質問を生成するよ う指示された。

学習講座 1 日目は介入を行わず, いずれの群の学習 者も，教科書を読んだ上で自由に質問を書き出した。 介入を導入した 2 日目から 4 日目までの予習時間には, 教科書のコピーと質問書き出しシートに加え, 予習を 行う際のポイントをまとめたプリントを配付した。自 由質問群に配付したプリントには, 教科書を読む際に 「いつ，どんな事件が起こったのか」，「誰（どの国）が どのような事をしたのか」を押さえた上で質問を作る ことが大切であると記載されていた。一方，質問介入 群と質問介入十解答作成群に配付されたプリントには,

予習の量自体に個人差が生じないようにするため, 本研究で は，家ではなく教室で，授業の冒頭に予習を行わせた。 
自由質問群と同様のポイントに加え，「なぜその人(国) がそのような行動をとったのか」，「なぜその出来事が 起こったのか」を理解できているか確認しながら質問 を作ることが大切であると記載されていた。教師(著者) は，プリントを配付した際に記載されているポイント を読み上げ，こうしたポイントにしたがって質問を書 き出すよう学習者に伝えた。

質問への解答作成 質問介入十解答作成群の参加者 は, 質問を生成するだけでなく, 予習中に解答作成も 行った。 2 日目から 4 日目までの質問介入十解答作成 群の「質問書き出しシート」には，質問を生成する欄 の右側に，それぞれの質問に対する解答欄が設けてあ り, 参加者は予習の中で, 質問生成と解答作成の両方 を行うよう指示された。また，自分の作った質問に解 答できるようになることが授業の目標であることが口 頭で伝えられた。

\section{従属変数}

予習時の質問生成数 本研究では, 介入によって学 習者の生成する質問が変容するかを検討するため, 毎 回の予習時間に生成された質問の数を従属変数として 測定した。

授業中のメモ 授業中に学習者が残したメモは, 授 業での情報選択を示す重要な指標である (e.g., Peverly, Ramaswamy, Brown, Sumowski, Alidoost, \& Garner, 2007)。 質問の生成方法への介入や，質問に対する解答作成に よって，授業目標の認識が促されるのであれば，授業 では質問に関連する情報のメモが増加するものと考え られる。そこで, 本研究では, 学習者が授業中に記入 したメモの測定を行った。なお，授業の中で残したメ モのみを正確に測定するため，ノートは毎回の授業後 に回収してコピーをとった上で，次の授業時に返却し た。

授業理解度 4 回の授業の理解度については, 篠ヶ 谷 (2011) と同様, 単語再生テストと因果説明テストを 用いて測定した。単語再生テストとは，教科書の記述 にある史実の記憶を問うテストであり，第一次世界大 戦の始まりから終わりまでを記述した文章中の 34 個 の空欄に，あてはまる人名や事件名の記入を求めた。 一方，因果説明テストとは，教科書に記述されている 史実の背景因果について説明を求めるテストであり,

「なぜイギリスはインドを支配したのですか？」など 15 問が出題された。

\section{結果}

分析対象者 本研究ではまず，5 日間の学習講座に
欠席しなかった参加者を分析対象とし，さらに，既有 知識の影響を統制するため, 今回の講座で扱った単元 である第一次世界大戦について，小学校，中学校，塾 のいずれにおいても「習ったことがある」と回答した 学習者は分析から除外した。その結果, 最終的な分析 対象者は自由質問群 25 名, 質問介入群 24 名, 質問介 入十解答作成群 25 名の計 74 名となった。

独立変数 本研究の分析では, 「予習時の質問生成に 介入を行うこと」と「生成した質問に対して解答を作 成すること」の影響を検討するため，1）質問生成へ の介入の有無，2）生成した質問に対する解答作成の 有無に関する 2 つ対比係数を用いた。1つ目の対比 を表すダミ一変数としては，自由質問群，質問介入群， 質問介入十解答作成群にそれぞれ-2，1，1 を割り当 て，2つ目の対比を表すダミー変数として，自由質問 群, 質問介入群, 質問介入十解答作成群にそれぞれ 0 , $-1,1$ を割り当てた。

共変量 本研究では, 事前の学力の影響を統制する ため, 事前質問紙で報告してもらった 5 教科の学校成 績の平均值について，1 以上 2 未満の学習者に 1,2 以上 3 未満の学習者に 2,3 以上 4 未満の学習者に 3 , 4 以上の学習者に 4 というダミー変数(学力ダミー)を割 り当てた。また, 国立大学附属中学校では, 学力試験 によって入学者の選抜を実施しているため, 附属中学 校の生徒と公立学校の生徒の学力には差があるものと 考えられる。そこで, 入学時の学力選抜の有無を表す ダミ一変数 (選抜ダミー) として, 附属中学校の生徒に 1 , 公立中学校の生徒に 0 を割り当てた。

さらに，5 日目に実施したテストのうち，1日目の 内容を問う問題の得点 (介入前得点) も，1) 各群におい て従属変数と有意な相関が見られる，2）処遇の効果 との間に交互作用が見られない，という 2 つ条件を 満たす場合に共変量として分析に投入した (c.f., 森・吉 田, 1990)。

事前質問紙の結果 事前質問紙の結果を Table 1 に 示す。学習者の意味理解志向に関する 4 項目の $\alpha$ 係数 を算出したところ，0.78 という值が得られたため， 4 項目の平均值を意味理解志向得点として算出した。先 述の対比係数を用いて分析を行った結果, 意味理解志 向得点に扔いて, 質問介入対比 $(t(71)=0.99, n . s$.$) , 解答$ 作成対比 $(t(71)=-0.01, n . s$.$) のいずれにおいても有意な$ 值は得られなかった。学校成績については質問介入十 解答作成群の 1 名分のデー夕が得られなかったため, 残った 73 名について同様の分析を行ったところ,質問 介入対比 $(t(70)=0.10, n . s$.$) , 解答作成対比 (t(70)=-0.11$, 
n.s.) のどちらの対比も有意ではなく，各群の学習者が 等質ではないことを示す積極的な証拠は得られなかっ た。

質問生成数の分析 予習時の質問の生成数について は，質問の質の違いを検討するため，「なぜ日本は日英 同盟を結んだのか」なな゙日本はシベリアに出兵したの か」といったように，史実の背景因果や知識間の関係 を問う質問 (高次質問) と，「資本主義とは」「協商って なんですか」「シベリア出兵には何人いきましたか」と いったように，語句の意味や史実の確認を行う質問(低 次質問)に分けてカウントを行った ${ }^{3}$ 。なお,「ルーズリー フってなんですか」などのように，歴史の授業に関係 のない質問は分析から除外した。質問の分類は教育心 理学を専攻する大学院生と筆者で行い, 一致率は 0.9 以上であった。不一致の部分については協議した上で 分類を行った。

各群の質問数の平均值および標準偏差を Table 2 に 示す。介入前にあたる 1 日目の予習時の質問数につい て, 学力ダミーと, 学力選抜ダミーを共変量とし, 2 つの対比係数を用いた分析を行ったところ，介入前の 高次質問数では, 質問介入対比が有意となり $(t(69)=$ $2.03, p<.05)$, 解答作成対比が有意傾向となった $(t(69)=$ $1.68, p<.10)$ 。一方，低次質問の生成数については質問 介入対比 $(t(69)=-1.08, n . s$.$) , 解答作成対比 (t(69)=-1.49$, n.s.）ともに有意な結果は得られなかった。

次に，介入後の 3 日間で生成された質問数について， 質問介入対比，解答作成対比，および，それらと意味 理解志向の交互作用の分析を行った。まず step 1 の重 回帰分析の独立変数に学力ダミー，選抜ダミー，質問 介入対比ダミー, 解答作成ダミー, 意味理解志向得点 を投入し, step 2 の独立変数には交互作用項として質 問介入対比ダミーと意味理解志向得点の積, 解答作成

Table 1 事前質問紙における各変数の平均值 $(S D)$

\begin{tabular}{|c|c|c|c|c|}
\hline & $\alpha$ & $\begin{array}{c}\text { 自由質問群 } \\
n=25\end{array}$ & $\begin{array}{c}\text { 質問介入群 } \\
n=24\end{array}$ & $\begin{array}{c}\text { 質問介入十 } \\
\text { 解答作成群 } \\
n=24\end{array}$ \\
\hline 意味理解志向 & .78 & $\begin{array}{c}3.40 \\
(0.83)\end{array}$ & $\begin{array}{c}3.58 \\
(0.66)\end{array}$ & $\begin{array}{c}3.58 \\
(0.70)\end{array}$ \\
\hline 学校成績 & - & $\begin{array}{c}3.57 \\
(0.89)\end{array}$ & $\begin{array}{c}3.61 \\
(0.90)\end{array}$ & $\begin{array}{c}3.58 \\
(0.82)\end{array}$ \\
\hline
\end{tabular}

質問書き出しシートの記述には「資本主義」「三国協商」と いったように，単語のみを記述したものも見られた。これらは 単語の意味が分からないことを明確化したものと考えられる ため, 本研究ではこうした記述も 1 つの質問として扱うことと した。
Table 2 質問生成数, メモ生起率，授業理解度の平 均值 $(S D)$

\begin{tabular}{|c|c|c|c|c|}
\hline & & $\begin{array}{c}\text { 自由質問群 } \\
n=25\end{array}$ & $\begin{array}{c}\text { 質問介入群 } \\
n=24\end{array}$ & $\begin{array}{c}\text { 質問介入+ } \\
\text { 解答作成群 } \\
n=25 \\
n=25\end{array}$ \\
\hline \multicolumn{5}{|c|}{ 予習時の質問生成数 } \\
\hline \multirow[t]{2}{*}{ 高次質問 } & 介入前 & $0.32(0.47)$ & $0.50(0.65)$ & $0.84(0.85)$ \\
\hline & 介入後 & $4.60(3.14)$ & $5.79(3.30)$ & $5.08(2.83)$ \\
\hline \multirow[t]{2}{*}{ 低次質問 } & 介入前 & $1.40(1.08)$ & $1.41(1.34)$ & $0.84(0.85)$ \\
\hline & 介入後 & $3.00(1.87)$ & $2.25(2.41)$ & $1.28(1.45)$ \\
\hline \multicolumn{5}{|c|}{ 質問関連メモ生起率 } \\
\hline & 介入後 & $0.20(0.31)$ & $0.15(0.21)$ & $0.32(0.30)$ \\
\hline \multicolumn{5}{|c|}{ 授業理解度得点 } \\
\hline \multirow[t]{2}{*}{ 単語再生 } & 介入前 & $2.16(1.99)$ & $2.79(1.84)$ & $2.44(2.27)$ \\
\hline & 介入後 & $10.96(6.17)$ & $12.91(7.06)$ & $12.72(7.84)$ \\
\hline \multirow[t]{2}{*}{ 因果説明 } & 介入前 & $3.28(2.28)$ & $3.20(2.65)$ & $3.80(2.58)$ \\
\hline & 介入後 & $8.64(5.31)$ & $8.37(4.69)$ & $10.24(4.96)$ \\
\hline
\end{tabular}

ダミーと意味理解志向の積を投入した。なお，調整変 数の素得点を用いて交互作用項を作成すると, 独立変 数間に高い相関が生まれてしまうが, 調整変数から平 均值を引くことでそのような問題を回避できるため (e. g., Cronbach, 1987), 意味理解志向得点は個々の学習者の 素得点からサンプル全体の平均值 (3.53) を減じた得点 を使用した。また，高次質問数については，すべての 群において介入前 (1日目) の質問数と介入後 (3 日間) の 質問数の間に有意な相関 $(r=.30 \sim .54)$ が見られたため, 介入前の質問数を共変量として分析に投入し，介入前 の個人差の影響を統制した。

分析の結果を Table 3 に示す。Figure 1 や Figure 2 に見られるように, 高次質問 $(\beta=-.20, p<.05)$, 低次質 問 $(\beta=.20, p<.10)$, いずれにおいても質問介入対比夕゙ ミーと意味理解志向の交互作用が存在することが示さ れ，質問の生成方法への介入の影響は，学習者の保持

Table 3 予習時の質問生成数を従属変数とした分析 結果

\begin{tabular}{lcclcc}
\hline & \multicolumn{2}{c}{ 高次質問数 } & & \multicolumn{2}{c}{ 低次質問数 } \\
\cline { 2 - 3 } \cline { 5 - 6 } & step 1 & step 2 & & step 1 & step 2 \\
\hline 学力ダミー & $.37^{* * *}$ & $.37^{* * *}$ & & .08 & .08 \\
選抜ダミー & $.29^{* * *}$ & $.28^{* * *}$ & & -.15 & .15 \\
質問介入ダミー & .03 & .02 & & $-.31^{* * *}$ & $-.30^{* * *}$ \\
解答作成ダミー & -.14 & -.13 & & $-.21^{* *}$ & $-.20^{*}$ \\
介入前得点 & $.42^{* * *}$ & $.41^{* * *}$ & & - & - \\
意味理解志向 & .01 & -.03 & & .11 & .15 \\
質問×意味理解志向 & & $-.20^{* *}$ & & & $.20^{*}$ \\
解答×意味理解志向 & & .04 & & & -.05 \\
\hline
\end{tabular}

Note. 数值は標準化偏回帰係数。

${ }^{*} p<.10 \quad{ }^{* *} p<.05 \quad{ }^{* * *} p<.01$ 


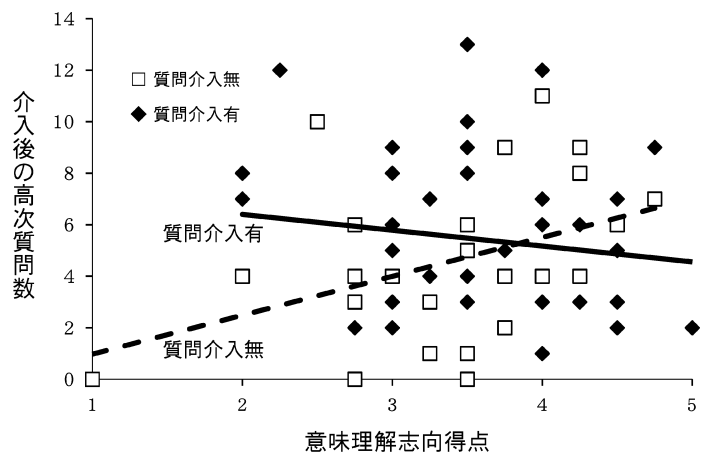

Figure 1 質問介入が高次質問数に与える影響

する信念によって異なる可能性が示唆された。

そこで, これらの交互作用についてさらに詳細な検 討を行うため, 本研究では Johnson \& Neyman (1936) による分析を行った。この分析は，交互作用の下位検 定の一つであり, 処遇の効果が生じる調整変数の範囲 を同定するものである。分析にはWeb上の分析ツー ル (Preacher, Curran, \& Bauer, 2006) を使用した。分析 の結果, 高次質問数に関しては意味理解志向得点が 2.05 以下の学習者の場合に, また, 低次質問数に関し ては意味理解志向得点が 3.76 以下の学習者の場合に, 質問生成への介入の効果が有意となることが示された。

授業中のメモの分析 本研究では, 自らが生成した 質問に関連する授業情報に注意を向けていたかについ て検討するため，授業中の学習者のメモに着目した。 しかし，質問に関連するメモの「数」を分析対象とす ると，質問の数が少ない場合，メモの数も必然的に少 なくなり，質問に関する情報に注意を向けていたかを 示す指標とはならない。そのため, 本研究では自ら生 成した質問に対するメモがどのくらいの割合で生起し たかという，「質問関連メモ生起率」を分析の対象とし

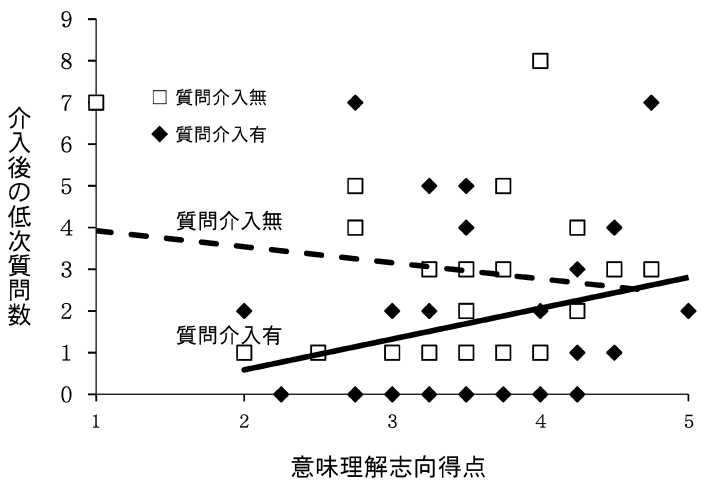

Figure 2 質問介入が低次質問数に与える影響

た。この得点は, 生成した質問に関連するメモの有無 について 0 - 1 でコーディングし，その合計を生成し た質問数で除して算出した。メモの有無の判断は教育 心理学を専攻する大学院生と筆者が行い, 不一致部分 については協議した上で分類した。なお，たとえ質問 を生成していても，関連する内容が授業で解説されな い場合にはメモをとることができないため，この得点 の算出では, 授業で扱われた内容に関する質問とメモ に絞った。また，1 日目の予習では，授業で扱われる 事項を問う質問を生成できている学習者が, 自由質問 群で 15 名, 質問介入群で 9 名, 質問介入十解答作成群 で 10 名しかいなかったため, メモ生起率の分析では, 介入後の得点のみを分析の対象とした（Table 2)。

質問生成数と同様に，2つの対比係数を用いて介入 の効果および意味理解志向との交互作用の分析を行っ たところ, Table 4 に示すように，質問介入ダミーと 意味理解志向の交互作用が有意となり $(\beta=-.21, p<$ $.05)$, 解答作成対比と意味理解志向の交互作用も有意傾 向となった $(\beta=.18, p<.10)$ 。下位検定の結果, 質問生成 への介入の影響については, 意味理解志向得点が 2.50

Table 4 メモ生起率および授業理解度得点を従属変数とした分析結果

\begin{tabular}{|c|c|c|c|c|c|c|}
\hline & \multicolumn{2}{|c|}{ 質問関連メモ生起率 } & \multicolumn{2}{|c|}{ 単語再生 } & \multicolumn{2}{|c|}{ 因果説明 } \\
\hline & step 1 & step 2 & step 1 & step 2 & step 1 & step 2 \\
\hline 学力ダミー & $.37^{* * *}$ & $.40^{* * *}$ & $.16^{* *}$ & $.15^{*}$ & $.28 * * *$ & $.27^{* * *}$ \\
\hline 選抜ダミー & $.28^{* * *}$ & $.29^{* * *}$ & $.14^{*}$ & .14 & $.21^{* *}$ & $.21^{* *}$ \\
\hline 質問介入ダミー & .04 & .03 & .05 & .05 & .03 & .03 \\
\hline 解答作成ダミー & $.29^{* * *}$ & $.27^{* * *}$ & .06 & .06 & $.15^{*}$ & $.16^{*}$ \\
\hline 介入前得点 & - & - & $.60 * * *$ & $.59^{* * *}$ & $.41^{* * *}$ & $.40^{* * *}$ \\
\hline 意味理解志向 & .11 & .05 & $.13^{*}$ & .12 & .13 & .13 \\
\hline 質問 $\times$ 意味理解志向 & & $-.21 * *$ & & -.07 & & -.06 \\
\hline 解答 $\times$ 意味理解志向 & & $.18^{*}$ & & -.07 & & .05 \\
\hline
\end{tabular}

Note. 数值は標準化偏回帰係数。 ${ }^{*} p<.10 \quad{ }^{* *} p<.05 \quad{ }^{* * *} p<.01$ 


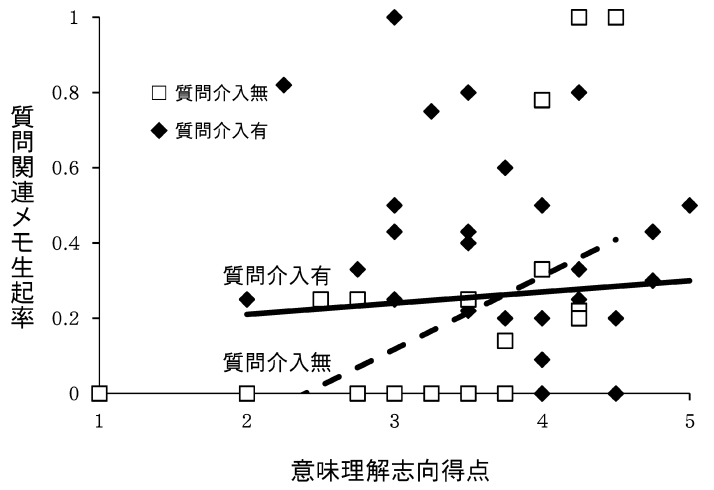

Figure 3 質問介入が質問に関するメモに与える影響

以下の学習者の場合に有意になることが示され(Figure 3), 解答作成の効果については，意味理解志向が 3.28 以上の学習者に対して有意となることが示された(Figure 4)。

授業理解度の分析 単語再生テストは 1 問正答につ き 1 点を配し (34 点満点), 因果説明テストは解答に必要 な 40 個の情報のリストを作成した上で, その情報の有 無についてコーディングを行い, その合計を得点とし た $(40$ 点満点)。各群の平均值と標準偏差を Table 2 に 示す。まず，介入前の内容に関するテスト得点につい ては, 単語再生テストでは有意な差は見られていな かった（質問介入; $t(69)=1.11, n . s$., 解答作成 $t(69)=0.03$, n.s.)。一方, 因果説明テストにおいては, 質問介入対比 では差が見られなかったが $(t(69)=1.11, n . s$.$) , 解答作成$ 対比の影響が有意傾向であった $(t(69)=-0.03, n . s$.$) 。$

次に, 介入後の内容に関する得点を従属変数として, 2 つの対比の影響および意味理解志向との交互作用の 分析を行った (Table 4)。その際，いずれのテストにお いても，共分散分析の前提が満たされたため，介入前 の内容に関する得点を共変量として投入した。分析の 結果，単語再生テスト得点では有意な結果は得られず, 因果説明テスト得点においても，解答作成の影響が示 唆された以外は $(\beta=.16, p<.10)$, 有意な結果は見出され なかった。

\section{考 察}

予習時の質問生成について 本研究の結果，史実の 背景因果や関連を問う高次質問の生成数においては, 2 つの対比の影響は認められなかったが，質問生成へ の介入と意味理解志向との間に有意な交互作用が見ら れることが示された。また，同様の交互作用は，語句 の意味や史実の確認を行う低次質問の生成数において

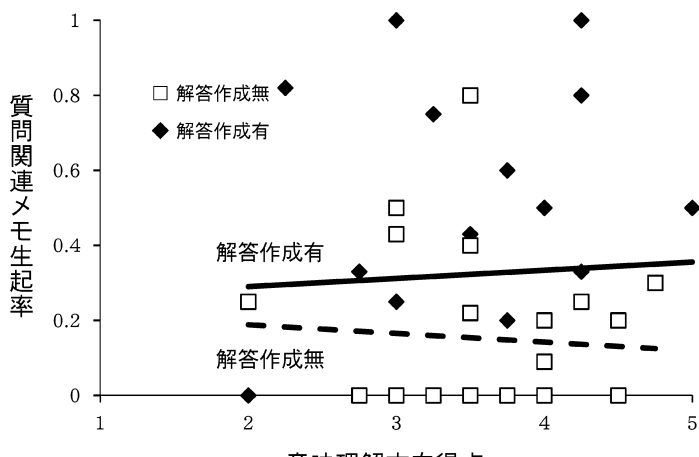

意味理解志向得点

Figure 4 解答作成が質問に関するメモに与える影響

も見られることが示唆された。

下位検定の結果，高次質問数においては，意味理解 志向が 2.05 以下の学習者の場合に質問生成への介入 の効果が有意となることが示された。本研究における 分析対象者の意味理解志向得点の平均值は 3.53 , 標準 偏差は 0.73 であるため, 2.05 は平均から $2 S D$ 以上離 れた, 非常に低い值である。したがって, 本研究の結 果から, 意味理解志向の極端に低い学習者の場合, 質 問生成に介入を行うことで，自由に質問を生成した時 よりも高次質問を多く生成するようになるといえる。

また，有意傾向ではあるが，本研究の目的から考え ると, 低次質問数においても交互作用の存在が示唆さ れたことは興味深い。下位検定の結果では, 意味理解 志向が 3.76 よりも低い学習者の場合に, 質問生成への 介入の効果が有意となることが示された。 3.76 以上の 学習者とは, 平均值よりも意味理解志向の高い学習者 である。したがって, 意味理解志向の高い学習者の場 合には，質問の生成に介入を行っても，低次質問の生 成数に変化が見られず，それ以外の学習者では, 低次 質問が減少するといえる。

本研究に打ける質問介入とは, 背景因果を問う高次 質問を生成するように促すことである。意味理解志向 の高い学習者は, もともと高次質問を生成し, 低次質 問は生成しない傾向にあるため，質問介入を行っても 高次質問数は増加せず，低次の質問もそれ以上少なく なることはない。一方, 意味理解志向の低い学習者の 場合，高次質問を生成するよう指導されることで，生 成する質問が変容したものと考えられる。

また，質問に対する解答作成については，低次質問 数を従属変数とした場合に, 解答作成ダミーの影響が 有意傾向となった。質問介入十解答作成群の場合には, 質問を生成した上で解答も書き出さなければならない。 
そのため，質問を生成するだけの場合に比べて，全体 的に質問数が減少する傾向にあるといえる。しかし， この群においても，質問生成に対して介入が行われ， 高次質問を生成するよう指導されているため，低次質 問のみが減少するのではないかと推察される。本研究 の分析では有意傾向であったが，予習指導を行うこと を考えた場合には，解答作成を行うことで，質問数が 減少する可能性があることには留意する必要があるだ ろう。

授業中の情報選択への影響 では，本研究における 質問生成への介入および質問への解答作成は，学習者 の授業中の情報選択にどのような影響を及ぼしたので あろうか。この点について, 本研究では, 生成した質 問に関するメモの生起率に着目して分析を行った。そ の結果, 質問介入ダミーと意味理解志向の交互作用が 有意となり, 意味理解志向の得点が 2.50 以下の学習者 に対しては，質問生成に介入を行うことで，メモの生 起率が上昇することが示唆された。

2.50 という意味理解志向得点は全体平均よりも 1 $S D$ 以上低い值である。このように意味理解志向の低 い学習者の場合, 知識同士を関連づける姿勢が弱いた め，自由に質問を生成させただけでは，自ら生成した 質問についてより理解を深めようとはしないものと考 えられる。しかし，質問の生成方法について介入を行 い，予習時にどのような知識を得ておくべきか，また， 授業ではどのようなことを理解すべきかを示すことで, 意味理解志向の低い学習者の目標認識が促され, 生成 した質問に関する授業情報の選択が促されたのではな いかと考えられる。

一方, 質問関連メモの生起率においては, 解答作成 の影響と意味理解志向の交互作用も存在する可能性が 示唆された。下位検定では, 意味理解志向得点が 3.28 以上の学習者に対して解答作成の効果が見られること が示された。逆に言えば，3.28 以下の学習者に対して はそのような効果は見られない可能性がある。意味理 解志向の平均值や標準偏差を考慮すると, 3.28 以下の 学習者は意味理解志向の低い学習者といえる。 Hamilton(1985)によれば，事前に提示された質問に対 して推論を行うことでその後の学習における目標認識 が促されるとされている。しかし，本研究では，生成 した質問に対して解答作成を行っても, 意味理解志向 の低い学習者の情報選択は促進されないことが示され た。こうした結果からは, 知識間の関連の理解を重視 する姿勢が弱い場合，たとえ推論を行っても，問いに ついて理解を深めることが目標として認識されない可
能性が示唆される。

授業理解度への影響 本研究の結果, 単語再生テス トでは有意な結果は得られなかったが，因果説明テス 卜において，単に質問生成に介入を行うだけの群より も, 解答を作成した群の方が, 因果説明テスト得点の 成績が高くなることが示唆された。

因果説明テストで説明を求められたのは, 教科書に は記述されて扔らず, 解説講義の中で初めて与えられ た背景因果である。そのため, この因果説明テストで は，予習で得た個々の史実の知識をもとに，授業中の 因果情報を統合できていたかが求められていたといえ る。ではなぜ予習時の解答作成によって授業中の統合 処理が促されたのであろうか。まず考えられるのは, 推論による個々の史実の知識の定着である。Pressley et al. (1990) は，事前に質問に対して推論を行っておく ことで関連する既有知識が活性化されるために，その 後の学習において新奇な情報を既有知識に統合しやす くなることを指摘している。こうした知見から，予習 時に単に高次な質問を生成するだけでなく，その問い に対する解答を試みることで, 教科書の記述にある 個々の史実の知識が強固となり, そのために, 授業中 の因果情報の統合が容易になったのではないかと考え られる。

ただし, 本研究では単語再生テスト得点において, 解答作成の効果が見られていなかったことから, 上記 のような解釈が成り立つ可能性は低い。そこでもう一 つ考えられるのは, 情報の外化がその後の学習に促進 的に機能した可能性である。伊東 (2004) は, 推論内容 を書き出すことが，外部記憶として機能することを指 摘している。そのため, 手元に推論情報が外化されて いる方が，頭の中で情報を比較・統合するよりも容易 に統合処理を行いやすくなるのかもしれない。無論, 解答作成の効果は有意傾向であり，このような影響が 示されたわけではない点には留意が必要である。

また，テスト得点において，質問生成への介入の影 響が見られなかったことも重要な結果であるといえる。 質問の生成方法の指導を行うと, 意味理解志向の低い 学習者の生成する質問が変容し, 授業中の情報選択が 促されるが，選択した因果情報と既有知識の統合が促 されるわけではない。そのため，テスト得点には質問 生成への介入の効果抢よび意味理解志向との交互作用 が見られなかったものと考えられる。

本研究の学術的意義 本研究では, 学習者の信念に 着目しながら，予習中の質問生成とその後の学習の関 係について検討を行った。質問生成に関する先行研究 
では，学習者の既有知識と質問生成の関係が示されて いるほか (e.g., Miyake \& Norman, 1979 ; Van der Meij, 1990)，質問生成に介入を行うことで，学習者の生成す る質問の質が変容することが示されてきた（e.g., 生田・ 丸野, 2005 ; King, 1992 ; 瀬尾, 2005)。しかし，これまでの 研究では, 学習者の保持する信念と, 学習者の生成す る質問の関係については明らかにされておらず，また， 質問生成への介入がその後の学習に及ぼす影響につい ても十分な検討は行われてこなかった。

こうした問題に対して, 本研究では, 事前の知識提 示によってその後の学習が促進されるまでのプロセス に, 学習者の質問生成や, その後の学習に向けた目標 の認識の個人差が関連していることが示唆された。こ うした知見は, 先行オーガナイザー研究や質問生成研 究の統合的な理解を可能とする意義深いものといえる だろう。

本研究の実践的意義 また, 教育実践への示唆とい う観点においても, 本研究の知見は意義深い。特に中 学校以降の教科学習では, 扱われる内容も高度になり, 授業で提示される情報量も増えるため，授業を一度聞 くだけで内容をすべて理解することは難しくなる。そ のため, 予習を積極的に導入し, 予習で分からなかっ た部分を授業で解消するスキルを育成することが不可 欠となる。

多くの教育現場においては，予習の指導を行う場合， 次に授業で扱う内容について教科書を読んでくるよう に指示するほかに，「下線を引く」「付箋を貼る」など して, 分からない部分をチェックしておくように促し ているものと考えられる。ところが，どこが分からな いかをチェックするには, 学習者は目標状態と自身の 現在の理解状態の差異を検出する必要があり, その差 異を評価することは非常に難しい（cf., Maki, Jonas, \& Kallod, 1994)。そのため, 予習を行わせる場合に, 漠然 と疑問点をチェックしてくるように指示しても, 学力 の低い学習者ほど「何が分からないのかが分からない」 といった状態に陥ってしまう可能性が考えられる。

援助要請に関する先行研究では, 漠然と感じた疑問 を，その後の学習へとつなげていくためには，疑問点 を質問の形で明確化しておく必要があることが指摘さ れており (e.g., 生田・丸野, 2005 ; 瀬尾, 2005), こうした知 見を踏まえて考えると，学力の低い学習者に予習を行 わせる場合にこそ, 漠然と疑問点をチェックさせるの ではなく，どのような知識を得た上で，どのような問 いを生成するべきかなど, 質問生成に対する介入を行 う必要があるといえる。しかも, 質問生成への介入を
行った場合に，ATI (適性処遇交互作用) が生じてしまう 可能性があるというのが, 本研究の重要な示唆である。

まず，質問生成の方法に対して介入を行わなければ， 学習者の信念によって生成する問いが異なってしまい, 授業で注意が向けられる情報にも個人差が生じてしま うといえる。しかし, 質問の生成方法に介入しても, 意味理解志向が非常に低い学習者の場合, 質問の質は 変容するものの, 授業理解が促進されるとは限らない。 また, 質問に対して解答作成を行わせることも, 授業 理解にポジティブに機能するものの, 推論を行うこと で目標認識が促されるかについては, 学習者の信念の 影響を受ける可能性があるといえる。

したがって, より多くの学習者の情報選択を促し, 授業理解を促進させるためには, 単に高次の質問を生 成させるだけでなく，その問いを解消することを授業 の目標として強く認識できるような工夫を行っていく 必要がある。このように, 予習を実際の学習指導に取 り入れる場合に考慮すべき点について, 具体的な示唆 が得られた点において, 本研究は高い実践的意義を有 するといえるだろう。

本研究の問題点と今後の展望 本研究では, 予習内 容の理解度について実際に測定を行っていないため, 因果説明テストにおいて解答作成の効果が見られた理 由について直接検討できているわけではない。この点 については, 今後, 予習後の知識の定着度を測定する などして検討を行っていく必要がある。

また, 本研究における予習活動が教育実践において 実現可能であるかについても留意する必要があるとい える。本研究での予習時間は 1 回につき 10 分であるた め, 日々の学習の中で実施することは可能であると考 えられる。しかし, 当然のことながら, 教科書を読む だけ，単に分からないところをチェックするだけと いった予習活動に比べ，「質問を生成する」，「自分なり の解答を書いておく」, といった予習活動の場合, 学習 者にかかる負担が大きい。そのため, たとえ効果的で あっても, 学習者が家庭学習において，こうした予習 活動を行えるようになるかは定かではない。

この問題については, 学習者に対して, いきなり家 庭で予習を行わせるのではなく, 本研究のように, 授 業の冒頭に予習時間を設けることが必要であると考え られる。その中で, 予習時に生成した問いをもとに, 授業理解を深めていくスキルを獲得させ, 予習活動の 有効性を実感させることで, 次第に家庭での予習活動 へと移行していけるようになるのではないだろうか。 いかにして学習者に予習の有効性を実感させ, 家庭で 
自発的に予習を行うように促していくかについては, 今後, さらなる検討が望まれる。

\section{引用文献}

Ausubel, D. P. (1960). The use of advance organizers in the learning and retention of meaningful verbal material. Journal of Educational Psychology, 51, 267-272.

Cronbach, L. J. (1987). Statistical tests for moderator variables : Flaws in analyses recently proposed. Psychological Bulletin, 102, 414-417.

Dahl, T. I., Bals, M., \& Turi, A. L. (2005). Are students' beliefs about knowledge and learning associated with their reported use of learning strategies? British Journal of Educational Psychology, 75, 257-273.

Dillon, J. T. (1988). Questioning and teaching : A manual of practice. New York : Teachers College Press.

Hamilton, R. J. (1985). A framework for the evaluation of the effectiveness of adjunct questions and objectives. Review of Educational Research, 1, 47-85.

市川伸一 (2004)。学ぶ意欲とスキルを育てるーい ま求められる学力向上策一小学館

生田淳一・丸野俊一（2005）。質問作りを中心にした 指導による児童の授業中の質問生成活動の変化 日 本教育工学会論文誌，29，577-586. (Ikuta，J., \& Maruno, S. (2005). Change of children's questioning in elementary school classes through question-generating centered instruction. Japanese Journal of Educational Technology, 29, 577-586.)

伊東昌子 (2004)。筆記説明が構成的学習に与える 影響 風間書房

Johnson, P. O., \& Neyman, J. (1936). Tests of certain linear hypotheses and their application to some educational problems. Statistical Research Memoirs, 1, 57-93.

Kardash, C. M., \& Howell, K. L. (2000). Effects of epistemological beliefs and topic-specific beliefs on undergraduates' cognitive and strategic processing of dual-positional text. Journal of Educational Psychology, 92, 524-535.

King, A. (1992). Facilitating elaborative learning through guided student-generated questioning.
Educational Psychologist, 27, 111-126.

Maki, R. H., Jonas, D., \& Kallod. M. (1994). The relationship between comprehension and metacomprehension ability. Psychonomic Bulletin \& Review, 1, 126-129.

Mayer, R. E. (1983). Can you repeat that? Qualitative effects of repetition and advance organizers on learning from science prose. Journal of Educational Psychology, 75, 40-49.

Mayer, R. E. (1996). Learning strategies for making sense out of expository text : The SOI model for guiding three cognitive processes in knowledge construction. Educational Psychology Review, 8, 357-371.

Miyake, N., \& Norman, D. A. (1979). To ask a question, one must know enough to know what is not known. Journal of Verbal Learning and Verbal Behavior, 18, 351-364.

森 敏昭・吉田寿夫 (1990). 心理学のためのデータ 解析テクニカルブック 北大路書房

Peverly, S. T., Ramaswamy, V., Brown, C., Sumowski, J., Alidoost, M., \& Garner, J. (2007). What predicts skill in lecture note taking? Journal of Educational Psychology, 99, 167-180.

Preacher, K. J., Curran, P. J., \& Bauer, D. J. (2006). Computational tools for probing interactions in multiple linear regression, multilevel modeling, and latent curve analysis. Journal of Educational and Behavioral Statistics, 31, 437-448.

Pressley, M., Tanenbaum, R., McDaniel, M. A., \& Wood, E. (1990). What happens when university students try to answer prequestions that accompany textbook material ? Contemporary Educational Psychology, 15, 27-35.

Rosenshine, B., Meister, C. \& Chapman, S. (1996). Teaching students to generate questions : A review of the intervention studies. Review of Educational Research, 66, 181-221.

瀬尾美紀子 (2005). 数学の問題解決に打ける質問 生成と援助要請の促進一つまずき明確化方略の教授 効果一 教育心理学研究, 53, 441-455. (Seo, M. (2005). Academic help-seeking and questiongenerating in mathematics : Role of strategies to check failures in problem solving. Japanese Journal of Educational Psychology, 53, 441-455.) 
篠ヶ谷圭太 (2008)。予習が授業理解に与える影響 とそのプロセスの検討一学習観の個人差に注目して 一 教育心理学研究, 56, 256-267. (Shinogaya, K. (2008). Effects of preparation on learning : Interaction with beliefs about learning. Japanese Journal of Educational Psychology, 56, 256-267.) 篠ヶ谷圭太 (2011). 学習を方向づける予習活動の 検討一質問に対する解答作成と自信度評定に着目し て一 教育心理学研究, 59, 355-366. (Shinogaya, K. (2011). Preparation for meaningful learning : Effects of a method involving answering prequestions and judging confidence in the answers. Japanese Journal of Educational Psychology, 59, 355-366.)

Van der Meij, H. (1990). Question asking : To know that you do not know is not enough. Journal of Educational Psychology, 82, 505-512.

\section{謝 辞}

本論文の作成にあたり, 丁寧なご指導を賜りました 東京大学教授市川伸一先生に心より感謝申し上げます。 また, 学習講座に参加してくださった中学生の皆様, 講座の実施に協力してくださった東京大学教育心理学 コース, 臨床心理学コースの皆様, 貴重なご意見をく ださった若手動機づけ勉強会の皆様に厚く御礼申し上 げます。なお, 本研究は日本学術振興会による科学研 究費補助金（特別研究員奨励費）を受けて行われまし た。

(2012.7.11 受稿, '13.7.8 受理)

\title{
Intervention During Preparation for Learning : Focusing on How to Generate Questions and on Answering the Questions Generated
}

\author{
KEITA SHINOGAYA (COLLEGE OF ECONOMICS, NIHON UNIVERSITY) \\ JAPANESE JOURNAL OF EDUCATIONAL PSYCHOLOGY, 2013, 61, 351-361
}

The present study examined effects of an intervention on how to generate questions during preparation for learning, in which participants were encouraged to answer the questions that they had generated, in the context of the learners' beliefs about learning. Junior high school students $(N=87)$ participated in the study, which was conducted for 5 days in experimental history classes. The students were assigned to 1 of the following groups: (a) generating questions freely during preparation for learning, (b) receiving an intervention on how to generate questions during preparation for learning, and (c) receiving an intervention on how to generate questions, in which they were encouraged to answer those questions. The results showed that the intervention on how to generate questions directed learners who thought that rote memorization was more important than understanding to generate more questions about the relations between facts. That intervention also directed these learners' attention during the lectures to information relating to the questions. In addition, answering the questions that they had generated during preparation increased learners' integration of information during the lectures, and therefore enhanced their understanding of the contents of the lectures.

Key Words : preparation for learning, generating questions, answering questions, beliefs about learning, history lessons 